\title{
Rehabilitating the Factor-Proportions Hypothesis
}

\author{
Bernard C. Beaudreau \\ Department of Economics, Université Laval, Québec, Canada \\ Email: bernard.beaudreau@ecn.ulaval.ca
}

Received 3 March 2015; accepted 12 April 2015; published 17 April 2015

Copyright (C) 2015 by author and Scientific Research Publishing Inc.

This work is licensed under the Creative Commons Attribution International License (CC BY). http://creativecommons.org/licenses/by/4.0/

(c) (i) Open Access

\begin{abstract}
The Heckscher-Ohlin theory of international trade remains an enigma. Despite being falsified on numerous counts [1] [2], it persists as the core theory of international trade, found both in undergraduate and graduate textbooks, not to mention in much research and policy. However, while it has failed to be confirmed by the data, the notion that factor proportions motivate trade, whether at the regional or national level, continues to hold sway. This paper is an attempt at rehabilitating the factor proportions hypothesis (FPH) as a theory of interregional and international trade. An alternative formalization, based on evolutionary principles (endogenous technology, mobile capital and labor), is presented and is used to rationalize the paradoxical findings of $\mathrm{HOH}$ empirical tests. The predictions are then tested using a variety of techniques. It concludes by examining the policy implications.
\end{abstract}

\section{Keywords}

Heckscher-Ohlin, Value Chain, Links, Stages, Tasks, Commercial Policy

\section{Introduction}

Despite being rejected empirically, the Heckscher-Ohlin theory $(\mathrm{HOH})$ of international trade remains at the core of trade theory and, to a certain extent, trade policy, owing in large measure to its intuitive appeal. The idea that trade is based on relative factor proportions is universal, cutting across cultures, time and space. This paper is an attempt to rehabilitate the Factor Proportions Hypothesis (FPH) of international trade. However, unlike recent attempts [2]-[4], it seeks to recast the theory from first principles. The gist of our argument is simple, namely that the failure of $\mathrm{HOH}$ trade theory owes in large measure to two oversights. First, the $20^{\text {th }}$ century witnessed paradigm changes in economic fundamentals. Fueling these were two developments, namely modernity [5] [6] with the accompanying vertical and horizontal production differentiation. Second, the early $20^{\text {th }}$ century wit- 
nessed the emergence of the transnational vertically-and horizontally-integrated corporation [7] [8]. Both had far-reaching implications for the factor-proportions theory of trade. For example, the ability to innovate complete with the resulting process and product technologies would now vary across regions and countries and like other endowments would become a key determinant of trade patterns [9]. Unfortunately, these two developments were ignored by both Eli Heckscher and Bertil Ohlin, and later by Paul Samuelson and others.

It will be shown that when the factor-proportions theory of international trade is set in the appropriate theoretical construct (e.g. one that includes a region/country's ability/endowment to innovate and vertical specialization and the presence of multinational and multiregional value chains), then most if not all of its predictions are borne out by the data. Moreover, it is shown that by doing so, it is no longer necessary to resort to a set of unrealistic assumptions (e.g. immobility of capital and labor) to generate predictions. Other than incorporating the idea of endogenous technological change (product and process) and the transnational firm into the corpus of $\mathrm{HOH}$ theory, this paper innovates in other important areas, notably in its approach to model in the relevant value chain perse. Typically, value chains are defined exogenously [10] [11]. That is, for a given product, a value chain consisting of $n$ vertical links/tasks is defined. We endogenize value chains by adding what we refer to as the visions-link which as its name indicates, consists of that stage at which the value chain for a given product is conceived of. As it precedes the value chain chronologically speaking, it is assumed to lie at the beginning (apex) of the vertical value chain. We shall refer to this as the vision-augmented value chain (VAVC).

Another important innovation is the concept of vertical comparative advantage [12]. Since time immemorial, the notion of horizontal comparative advantage has dominated the debate over trade. Implicitly, it has been assumed that goods are produced entirely in a given legal jurisdiction (state, country, etcetera). The emergence and growth of the transnational firm has invalidated and continues to invalidate this assumption [13] [14]. ${ }^{1}$ As such, regions and countries do not have a comparative advantage in the production of goods, but rather, a comparative advantage in a particular sub-process (link)/stage/task of production of goods. For example, resource rich regions-countries will have a vertical comparative advantage in the upstream resource links.

As our model allows for perfectly mobile capital and labor (traditional factors), the question of long-run vertical comparative advantage arises. If capital and labor are free to migrate, then factor-price equalization will remove any and all forms of comparative advantage, and ultimately end trade altogether [16] or so it was believed. To address this problem, we propose two types of comparative advantage are examined, namely structural comparative advantage and arbitrage comparative advantage. The former includes the ability to conceive of value chains (goods and services) and natural resources, while the latter includes a capital or labor-based comparative advantage. It is important not to confuse the ability to conceive of value chains with the value chains themselves. The latter are exportable say via managerial defections and the establishment of foreign rivals, while the former is not as it is cultural in nature

The paper is organized as follows. We begin by presenting a brief history of the FPH, focusing on its evolution over time, especially in the $20^{\text {th }}$ century. This is followed by our model which introduces evolutionary principles into the standard trade framework. It does this by rendering technology endogenous, the supply of which is determined by a country's innovation culture and the corresponding flow component, namely its endowment of visionaries and scientists. The predictions of the model are then used to rationalize the paradoxical findings of $\mathrm{HOH}$ empirical tests. Various trade indices (regional and international) are used to support the predictions of the model. Specifically, the GFPH predicts that regions and countries that are relatively well endowed in so far as its ability to produce visionaries and scientists will export what Elhanan Helpman referred to as headquartering activity [17]; that regions and countries which are relatively well-endowed in natural resources will export raw materials (transformed endowments); and that states and countries which are well endowed with labor will export midstream value added (manufacturing activity). Last, we examine the policy implications of global value chains and vertical comparative advantage.

\section{FPH: Literature Review}

The idea behind the FPH and $\mathrm{HOH}$ is relatively simple, not to mention intuitive, namely that if someone has more of something relative to another thing than someone else, then should trade occur, his/her something will be traded against the other thing. It matters little what the something actually is. It could be material as it could

\footnotetext{
${ }^{1}$ In fact, it could be argued that trade in general since the Renaissance and even before violates this assumption. As [15] argues, trade has since time immemorial been vertical in nature. Early empires can be seen as country-wide value chains.
} 
be immaterial. Examples include: charm for sustenance, organization for security, and/or affection for wealth. In this section, we examine the FPH and HOH from a historical perspective, focusing our attention on three periods, namely the classical period (prior to $\mathrm{HOH}$ ), the $20^{\text {th }}$ Century and the $21^{\text {st }}$ Century. Within each period, we will be interested in ascertaining both the breadth of the endowment (i.e. the basis of trade) and its relationship to trade in general. For example, is it restricted to material factor inputs (capital and labor) or does it extend beyond?

Trade is inherently based on the presence of asymmetries. This is true of all forms of trade, whether they be material in nature or not. For example, it holds in human relationships, where differences across individuals are a source of attraction and a basis for trade. Which leads us to our first observation, namely that because of its intuitive nature, the FPH is probably as old as human thought in general, and intellectual endeavors (writing) in particular. Put differently, any treatise, written or other, of trade would have invariably considered factor proportions as a-if not the-basis for trade.

This being said, let us turn to the question of paternity, proper. When and where did the modern FPH arise? And under what circumstances? As in all cases involving intellectual paternity, the evidence is sparse and inconclusive. Bertil Ohlin himself attributed the $\mathrm{HOH}$ to French works, specifically to the writings of Jean-Charles Léonard Sismonde de Sismondi who in De la Richesse Commerciale that the comparative abundance of capital and labour in different countries determines their territorial specialisation as between industries requiring relatively much labour and those requiring relatively much capital. Simon Power, however, rejected this view, arguing that De la richesse commerciale is a work lacking in originality, being a popularization of the ideas of Adam Smith.

Perhaps Ohlin was referring to earlier French writers, pointing specifically to Turgot to whom the following quote is attributed:

Effectively, all one need do is to reflect upon the immense quantity of charcoal used in the reduction of metal and the equally immense quantity used in the production of iron, to convince oneself that however abundant the mineral, it cannot be brought into production unless it happens to be located near a large quantity of wood and that the wood has little value. The production and sale of iron is assigned by nature to new nations, nations which possess vast untouched forests, far from all outlets, where one finds it advantageous to burn an immense quantity of wood for the sole value of the salts that one gains from washing the remaining cinders. This commerce, weak in England, still flourishing in France, much more in Germany and in the North, should, following the natural course of events, be taken up in Russia, in Siberia, and in the American colonies, until such time as they themselves become highly populated, and all nations find themselves in equilibrium, and until the increase in the price of iron is strong enough to renew interest in its production in those countries where it had been abandoned, the result of not being able to compete with the poorer nations. [18]

However, he rejected this view, pointing out that Turgot himself was strongly influenced by the English economist Josiah Tucker. He concluded by noting that the HOH has a "far longer history that Ohlin was aware of, and it would seem most unlikely that it was first touched upon in French works”. We concur and hasten to add that the equivocal nature of its historical antecedents speaks in large measure to the intuitive nature of the FPH. We would go further and add that the FPH is as old as trade itself, extending back millennia to the early empires and beyond.

It is interesting to note that Eli Heckscher was first and foremost an economic historian and author of an exhaustive history of mercantilism. It could be argued that anyone studying the history of early empires could not but hold the FPH as the guiding principle underlying world trade. This brings us to Eli Heckscher's seminal 1919 paper where he introduced the HOH for the first time. Specifically, he examined trade through the prism of factor proportions, focusing on three inputs, namely land, labor and capital. Technology was assumed to be symmetric, making for the situation in endowments and factor intensities determined trade flows.

Clearly, this assumption was critical. Unlike the Ricardian model where comparative advantage was based in large measure on technological asymmetries, Heckscher had leveled the playing field, so to speak. With the benefit of hindsight, this assumption seems both misguided and misplaced. After all, Heckscher was an economic historian, having written the history of British industrialization. But more importantly, Heckscher wrote at a time of massive technological change in the form of the second industrial revolution. Ironically, he was unable-or unwilling - to acknowledge a nation's endowment in science as a possible source of comparative ad- 
vantage.

The second industrial revolution witnessed paradigm process and product innovations, not to mention the shift of economic, military and political power to the United States. US-based multinational firms with their new process and product technologies conquered the planet, including Sweden. Great Britain was in decline, as was most of Europe. In short, if there was one factor endowment that marked to the point of defining Heckscher's era, it was the ability to innovate in general, and the US' ability to innovate in particular. ${ }^{2}$ One could go as far as to argue that Heckscher was in the wrong place at the wrong time. The early $20^{\text {th }}$ century was anything but a period of stable technology. In fact, it could be argued that most of the $20^{\text {th }}$ century was characterized by, to the point of being defined by, changing processes and changing products.

Not surprisingly, the $\mathrm{HOH}$ performed poorly, empirically speaking. After all, proprietary technology against a backdrop of global vertical integration violated two of the model's most important assumptions, namely symmetric technology and immobile factors. In the late 1990s, an attempt was made to "salvage" the HOH by invoking country-wide technology and preference asymmetries. Using a 1983 data set consisting of nine factors and 33 countries, Daniel Trefler was unable to corroborate the HOH. In fact, he went further by alleging the presence of missing trade, which by definition is the absence of trade despite a non-negligible factor endowment. Also, he found that rich countries (i.e. the North) were scarce in most factors, while poor countries were abundant. Pushing the analysis further, he invoked two possible explanations, namely the existence of higher productivity in the North and asymmetric preferences. Both hypotheses were tested and confirmed by the data. Davis and Weinstein showed that when the $\mathrm{HOH}$ is modified to permit technical differences, a breakdown of factor price equalization, the existence of non-traded goods and costs of trade, it is consistent with the data for 10 OECD countries.

The problem with this literature, however, is its apologetic nature-specifically, the $\mathrm{HOH}$ as originally formulated by Heckscher and Ohlin is hardly recognizable. The $\mathrm{HOH}$ was about trade being determined by relative factor endowments (capital and labor) in a world of symmetric technology. In this literature, trade is determined by a host of other factors, the origins of which are exogenous to the model. This is where our works enters. Namely, if (i) technology is indeed asymmetric and (ii) technology is not exogenous [19], but rather is determined by a country's endowment of visionaries and scientists, then it stands to reason that a more complete reformulation of the FPH would include the determinants of technology as legitimate factor inputs and hence as sources of comparative advantage and trade.

While these authors have addressed the question of technology and possible ex-post rationalizations, they have failed to address two important shortcomings of the $\mathrm{HOH}$ literature in general, namely, the presence of global value chains (throughout the period under study, namely the $20^{\text {th }}$ century), the use of value-of-shipments as opposed to value added data and its aggregative nature. For example, Daniel Trefler assumes that all firms and all sectors of the US economy have the same productivity advantage over their foreign rivals. US copper mines are twice as productive as foreign ones despite the fact that in many cases, the latter are owned and operated by US firms. Lastly, because $\mathrm{HOH}$ (or alternatively HOV) empirical tests use value-of-shipments data, they invariably yield biased and unreliable results. In fact, one could go as far as to argue that value-of-shipments data explains the mystery of the North's sizeable trade volumes in the face of what are few abundant factors. More specifically, they bias the value of the North's exports upwards. To be valid, large-scale HOH tests require value added-based export and import data.

This paper attempts to deal with these problems, both theoretically and empirically, First, it begins with a general formalization in which both material (land, labor, capital, energy) and immaterial (the propensity to innovate) factor endowments are considered at the industry level. The resulting generalized factor proportions hypothesis (GFPH) is a more complete and far-reaching theory of international trade, one that is both intuitive and practical and one which includes Eli Heckscher and Bertil Ohlin's version as a special case.

\section{Analytical Framework}

For our purposes, the problem of international trade will be modeled as an optimal assignment problem where the social planner maximizes social welfare by assigning the links of value chains to regions or countries on the basis of vertical comparative advantage. In so doing, he maximizes the overall, system-wide gains from trade,

\footnotetext{
${ }^{2}$ However, unlike land, labor and capital, the ability to innovate is a more difficult concept to measure. Put differently, it does not offer itself as a readily measurable metric.
} 
and in the process maximizes welfare. However, for our specific purposes, we assume that the social planner is replaced by firms that solve a similar optimal assignment problem. Specifically, the representative profit-maximizing firm will localize in geographical space, the various vertical stages (or links/tasks) of the production value added chain on the basis of vertical comparative advantage.

Our starting point is the vision-augmented value chain (VAVC) which consists of an analytical representation of the various stages which together define the final product [20] [21]. In keeping with the business strategy literature, specifically with the evolutionary character of VAVCs over time [22], we consider a three-stage model. In the first stage, VAVCs are conceived of by visionaries/entrepreneurs/managers. Typically, this will involve either a new product and/or a new process and will be the result of a "vision-creating processes", as well as the establishment/localization of the various links of the value chain. Included in the vision are (i) the product's characteristics (hereafter defined as $\Theta$ ), (ii) the corresponding processes and sub-processes defined at the link level, and (iii) the firm's operational strategy. Conceptually, a firm's product/process characteristics (i.e. $\Theta$ ) can result from (i) a given entrepreneur/manager's imagination (e.g. Henry Ford, George Westinghouse, Nikolai Tesla), (ii) informal R \& D, and/or (iii) formal R \& D (i.e. R \& D laboratory), or be acquired on the market for intellectual property.

The result is a set of VAVCs that run across industries and sectors, each corresponding to a particular product. In the second stage, individual VAVCs take shape with the creation of vertically-integrated value chains localized across regions/countries, the latter being defined primarily in terms of relative factor endowments and relative factor prices. In the third stage, VAVCs produce, sell and report earnings and a filter is then applied. Those that are profitable/successful (or competitive) go on to the next round/period and enter into the relevant set of VAVCs, while the others are meted out. In the next round/period, a similar three-stage process occurs with the surviving VAVCs and new ones that will have since come into being. Accordingly, there is no equilibrium in the conventional sense as new VAVCs are forever being conceived of while existing VAVCs are being meted out. $^{3}$

We now turn to the Stage 2 optimization problem. For analytical purposes, we refer to the VAVC as the lead/initial link. Let $v_{i j}$ represent value link $i$ of chain $j$, where $i=1,2,3, \cdots, m_{j}, m_{j}$ being the number of links in the $j^{\text {th }}$ value chain. Equation (1) describes the first Stage 2 link, while Equation (2) describes the $m_{j}-1$ remaining Stage 2 links. The former describes the resource link/stage/task and consists of the flow of resources, while the latter describe the relevant Leontief fixed-proportions process technology for the remaining links, defined in terms of $k_{i j}$ capital and $n_{i j}$ labor. ${ }^{4}$ Factor intensities are assumed to vary across links and hence within individual value chains. In general, upstream links (primary sector) are capital intensive, while manufacturing links (secondary sector) are more labor intensive (however, increasingly less so, with the advent of control technologies). Lastly, downstream links (e.g. advertising, distribution and marketing) are highly labor intensive.

Equation (3) describes the corresponding, link-level unit cost equation for location l, while Equation (4) describes the relevant Leontief fixed-proportions final good production function defined over all $m_{j}$ stages/links. The $\beta$ 's are the corresponding Leontief fixed-proportions value-added technology parameters.

$$
\begin{gathered}
v_{1 j}=\rho \\
v_{i j}=\min \left[\frac{\rho_{i j}}{\alpha_{\rho_{i j}}}, \frac{k_{i j}}{\alpha_{k_{i j}}}, \frac{n_{i j}}{\alpha_{n_{i j}}}\right] \quad \forall i=2,3,4, \cdots, m_{j} . \\
c_{i j l}=\alpha_{\rho_{i j}} p_{\rho_{l}}+\alpha_{k_{i j}} p_{k_{l}}+\alpha_{n_{i j}} p_{n_{l}} \quad \forall i=1,2,3,4, \cdots, m_{j} .
\end{gathered}
$$

\footnotetext{
${ }^{3}$ This framework is consistent with the evolutionary regime in evolutionary economics, defined by the following three-phase sequence: In the first phase, generic ideas originate; in the second phase, macroscopic (population-level) adoptions governed by various mechanisms (selection, path dependence, learning effects etc.) occur; in the third phase, stabilization based on high-frequency adoption, happens.

${ }^{4}$ Energy enters the analysis via resources. However, in addition to being a factor input, it is also a link (sub-link) for each of the $m_{j}$ links. The idea here is straightforward. Energy rich regions/country will hold a vertical comparative advantage in the extraction/refinement of the energy in question. However, once extracted and transformed (refined/transported), it will enter each of the remaining $m_{j}$ links as a factor input (not an intermediate product or semi-finished good). Hence, energy sources will be a factor in structural vertical comparative advantage (e.g. Saudi Arabia); however, energy products per se will constitute links/sub-links for all other activities. However, in cases where the energy in question is immobile (e.g. hydroelectricity), it stands to reason that energy can, conceptually speaking, constitute a source of a structural vertical comparative advantage.
} 


$$
\begin{gathered}
q_{j}=\min \left[\frac{v_{1 j}}{\beta_{1 j}}, \frac{v_{2 j}}{\beta_{2 j}}, \frac{v_{3 j}}{\beta_{3 j}}, \cdots, \frac{v_{m j}}{\beta_{m j}}\right] \\
c_{j l}=R / q_{j}+\beta_{1} c_{1 j l}+\beta_{2} c_{2 j l}+\beta_{3} c_{3 j l}+\cdots+\beta_{m j} c_{m j l}
\end{gathered}
$$

Equation (5) describes the corresponding cost equation (Stages 1 and 2) for a given region/country (i.e. l). $R$ corresponds to the ex-post VAVC-specific, Stage 1 profits/rents. ${ }^{5}$ As such, the resulting unit VAVC cost (Stage 1 ) is a decreasing function of $q_{j}$, the quantity of the final good/service produced. $c_{1 j l}$ corresponds to the cost/price of resources in location $l$. These are typically referred to as royalties. Here, the $\beta_{i j}$ 's correspond to the relevant Leontief value-chain input-output parameters. That is, to the number of physical units of link $i$ output in the $j^{\text {th }}$ value chain.

We now proceed to model the firm's link localization decision — that is, the localization in geographical space of the $m_{j}$ Stage 2 links of the representative value chain. Specifically, link localization is modeled in terms of classical optimization behavior (Equation (6)) where the firm (owners of the relevant VAVC) maximizes perunit profits/minimize costs by choosing the set of localizations $\Lambda$ for the $m_{j}$ Stage 2 links across the set of regions and countries [23].

As such, the localization of the $m_{j}$ Stage 2 links will be based on relative factor abundance as measured by relative factor endowments and the corresponding relative factor prices. ${ }^{6}$ For example, countries that are labor abundant (e.g. Asia, India, Mexico) will/should have lower-than-average wages and, as such, will/should attract investment on the part of firms wanting to localize their labor-intensive links there. The presence of trade barriers can however affect the outcome. Tariffs on imports of natural resources, semi-finished or finished products will, in general, favor source country (i.e. the VAVC region/country) investment for obvious reasons, as will various investment incentives (subsidies, tax incentives, local-content clauses). Likewise, restrictions on natural resource exports (unprocessed) will affect localization decisions.

$$
\max _{\{i j\}\}} \pi=p_{j}-\beta_{1 j} c_{1 j l}-\beta_{2 j} c_{2 j l}-\beta_{3 j} c_{3 j l}-\cdots-\beta_{m j} c_{m j l}
$$

Consequently, the localization of the $m_{j}$ Stage 2 links that comprise a given value chain will be based on the concept of relative factor abundance as measured by relative factor input prices. For example, regions/countries that are labor abundant (e.g. Asia, India, Mexico) will/should have lower-than-average wages and, as such, will/ should attract investment on the part of firms wanting to localize their labor-intensive links there. The presence of trade barriers will affect the outcome, forcing firms to localize production links in a sub-optimal fashion. Tariffs on imports of natural resources, semi-finished or finished products will, in general, favor home region/ country investment for obvious reasons, as will various investment incentives (subsidies, tax incentives, localcontent clauses). Likewise, restrictions on natural resource exports (unprocessed) will favor home region/country investment also. That is, the representative VAVC will localize more Stage 2 links in the natural resourceabundant region.

In the third and final stage, the market (consumers) selects from among the available VAVCs. Successful VAVCs will cover their costs and earn non-negative profits, while unsuccessful ones will be forced out. This corresponds to the selection stage [22]. Successful VAVCs will continue into the next stage, whereas unsuccessful ones will be forced out of the market. In some cases, the failure of a specific VAVC may be met with revisions/ modifications, or the VAVC may be simply dismantled and sold-off. As it turns out, this is a common occurrence. Large, multi-VAVC corporations will oftentimes sell off some of their product divisions (e.g. IBM selling its PC division to Le Novo, Bombardier selling its recreational products division to Bain Capital), focusing on either the most profitable ones, or ones that are related to their core activities.

\section{The GFPH and Vertical Comparative Advantage}

This simple approach allows us to generate a number of predictions regarding regional/national vertical comparative advantage. More specifically, region/country-based vertical comparative advantage (Stages 1 and 2 combined) will be based on the relative endowments of four factor inputs, namely (i) the ability to generate VAVCs (knowledge), (ii) natural resources, (iii) capital and (iv) labor. The ability to generate VAVCs refers to a region/

\footnotetext{
${ }^{5}$ This can be interpreted as the return to intellectual property, or intangible assets.

${ }^{6}$ For more on the sourcing problem, see [23]-[25].
} 
country's ability to generate new products and processes-in short, innovate (Stage 1). This will depend on a number of factors—social, cultural, historical and economic [26] [27]. Accordingly, regions/countries will differ in their ability to innovate-and hence to generate VAVCs.

Here, we consider Stages 1 and 2 simultaneously. Specifically, an additional link (i.e. the conception of the VAVC) is added to the $m_{j}$ Stage 2 links. By combining both the attributes of a region/country (as defined by its endowments of the four factor inputs), with the exigencies of the value chain (for all $m_{j}+1$ links), we can formalize link localization in terms of a simple assignment problem. That is, assign a particular link to its most likely localization. In other words, links that are labor intensive will be localized in labor-abundant regions/ countries, those that are capital intensive will be localized in capital-abundant countries, etcetera. Certain regions/countries will hold a vertical comparative advantage in the conception of VAVCs and will consequently be home to the resulting corporations (headquarters). A good example is Silicon Valley in California, or Bangalore in India. Other regions/countries will hold vertical comparative advantages in resources, in labor or in capital. Equations (7) and (8) formalize this process in probabilistic terms. Specifically, $p_{1 j}$, the ex-ante probability that link the resource link of the $j^{\text {th }}$ value chain will be localized in region/country $l$, is modeled as an increasing function of its relative resource endowment - that is, relative to the rest of the world (Equation (7)) Secondly, $p_{i j}$, the ex-ante probability that link $i j$ will be localized in region/country $l$, is modeled as an increasing function of the technological exigencies of link $i j$ as they relate to the factor endowment of region/country $l$, defined as the inner product of the two factor intensities (i.e. the $\alpha_{i j}$ 's) and the ratio of region/country l's endowment to the overall world endowment (Equation (8)). For example, if $\alpha_{k}$ is high, and $k_{l} / k_{w}$ is low, then the probability that region/country $l$ will attract the capital intensive link will be low. That is, the region/country in question doesn't have the wherewithal to attract capital-intensive links. As a rule, the more a region/country is well-endowed in a factor input, the greater is the probability that it will attract links that makes intensive use of it. ${ }^{7}$ If region/country $l$ is capital abundant (i.e. its relative share of the overall world capital stock is non-negligible), then it will attract capital-intensive links.

We now turn to the Stage 2 optimization problem. Let $v_{i j}$ represent value link $i$ of chain $j$, where $i=1,2,3, \cdots, m_{j}$, $m_{j}$ being the number of links in the $j^{\text {th }}$ value chain. Equation (1) describes Stage 2 link $i j$ 's process technology, defined over three inputs, $\rho_{i j}$, natural resources, $k_{i j}$ capital and $n_{i j}$ labor. ${ }^{8}$ Factor intensities are assumed to vary across links and across value chains. In general, upstream links (primary sector) are resource and capital intensive, while manufacturing links (secondary sector) are more labor intensive (however, increasingly less so, with the advent of control technologies). Lastly, downstream links (e.g. advertising, distribution and marketing) are highly labor intensive.

$$
\begin{gathered}
p_{1 j l}=f\left[\frac{\rho_{l}}{\rho_{w}}\right] \\
p_{i j l}=f\left[\alpha_{k_{i j}} \frac{k_{l}}{k_{w}}, \alpha_{n_{i j}} \frac{n_{l}}{n_{w}}\right] \forall i=2,3,4, \cdots, m_{j}
\end{gathered}
$$

This approach to link/stage/task localization and vertical comparative advantage ignores countless factors that will otherwise affect the firm's decision, from history, to trade barriers, to transactions costs, to other factors such as nationalism. Link localization in any given case may, as such, not be optimal in the sense referred to here. As a result, there is every reason to believe that from an empirical point of view, the localization decision will be probabilistic as opposed to deterministic in nature. That is, the very presence of relative factor abundance in a given region/country can be seen as increasing the ex-ante probability that it will attract a compatible link (as defined by factor intensities), but will not as such guarantee its presences. Capital-abundant region may or may not attract all capital-intensive links; however as conceptualized, the presence of a cost differential will in-

\footnotetext{
${ }^{7}$ Econometrically speaking, it consists of a Probit $(0-1)$ model with the various factor intensities and factor endowments as the independent variables.

${ }^{8}$ Energy enters the analysis via the resource input. However, in addition to being a factor input, it is also a link (sub-link) for each of the $m_{j}$ links. The idea here is simple. Energy rich regions/country will hold a vertical comparative advantage in the extraction/refinement of the energy in question. However, once extracted and transformed (refined/transported), it will enter each of the remaining $m_{j}$ links as a factor input (not an intermediate product or semi-finished good). Hence, energy sources will be a factor in structural vertical comparative advantage (e.g. Saudi Arabia); however, energy products per se will constitute links/sub-links for all other activities. However, in cases where the energy in question is immobile (e.g. hydroelectricity), it stands to reason that energy can, conceptually speaking, constitute a source of a structural vertical comparative advantage.
} 
crease the ex-ante probability.

\subsection{Sectoral/Strands of Links Comparative Advantage}

Sectoral comparative advantage can be defined as entire-value chain comparative advantage and corresponds to the notion of horizontal comparative advantage found in classical and neoclassical trade theory. As our value chains are the sum of the $m_{j}+1$ Stages 1 and 2 links, and strands of links, it stands to reason that sectoral horizontal comparative advantage can be defined and potentially estimated for each localization (region and/or country). For example, for region/country A to have a horizontal comparative advantage in value chain $j$, its relative final-good price (vis-à-vis value chain $j l$ ) would have to be lower than in region/country B. That is, the cost of localizing all $m_{j}+1$ links in region/country A, relative to the same cost of a numéraire good (i.e. s), would have to be less than in region/country B.

In the context of globally-dispersed value chains, the very meaning of horizontal comparative advantage is very much in question [28]-[32]. History shows that value chains have been rarely region/country specific, are rarely region/country specific and will no doubt continue to be rarely region/country specific. Since time immemorial (i.e. early trade empires), value chains have been geographically dispersed, making conventional horizontal comparative advantage a largely irrelevant (theoretically and empirically) and meaningless concept. For example, nineteenth-century Great Britain did not have a horizontal comparative advantage in textiles, but rather, had two vertical comparative advantages, namely a Stage 1 knowledge-based vertical comparative advantage in the conception of high-throughput, value chains and secondly, a Stage 2 vertical comparative advantage in the processing of the various fibers imported from its colonies.

The emphasis on either defining or formalizing sectoral horizontal comparative advantage at the country level, we believe, is, in large measure, to blame for the failure of comparative advantage to make important inroads in the empirical trade and policy literature. The value chains and the material processes that characterize most material processes today are infinitely more complex than the trivial production functions/relationships found in international trade text books. Moreover, as pointed out, from time immemorial, value chains have been dispersed across regions/countries, making horizontal comparative advantage little more than an abstraction.

\subsection{The GFPH-Based Vertical Comparative Advantage Taxonomy}

Our approach easily lends itself to various categorizations of regional/national vertical comparative advantage, starting at the very top/beginning of value chains (Stage 1), namely the ability of a region/country to generate/ conceive of VAVCs (i.e. product and process visions).

Specifically, it can be argued that certain regions/countries will have a vertical comparative advantage in generating/conceiving of firm visions defined in terms of product(s) and their associated production processes (i.e. the business process). This is analogous to what Elhanan Helpman referred to as headquartering activity and consists of the ability to generate new visions (i.e. new products, new processes). Its presence will depend on a number of factors, including R \& D expenditure, education, and the overall level of innovation in the region/ country [33]. Other regions/countries will have a Stage 2 vertical comparative advantage in natural resources based on their endowments. These include metallic and non-metallic ores, various chemical elements, energy and other carbon-based products (biomass). We assume that both of these vertical comparative advantages are, in the spirit of the Heckscher-Ohlin approach, exogenous (at least in the short run) and immobile. That is, the Stage 1 capacity to generate VAVCs not the VAVC itself, and natural resources will be considered immobile across localizations. ${ }^{9}$ The former owes to the social, political, historical and cultural nature of innovation [34]. Certain regions/countries are, owing to structural factors, more likely to generate Stage 1 VAVCs. What's more, because this advantage is rooted in the social and intellectual fabric of the region/country, it is not transferable (i.e. immobile).

To refine the analysis, we distinguish between two types of vertical comparative advantage, namely structural and arbitrage (see Table 1). Structural vertical comparative advantage refers to either the Stage 1 ability to gen-

\footnotetext{
${ }^{9}$ For example, iron ore is assumed to be immobile; however, pig iron or steel is not. Likewise, oil wells are immobile; however, the oil itself is not. There are, of course, exceptions such as hydroelectricity which cannot be transported over long distances. In this case, both the resource and the output are immobile and hence a source of structural comparative advantage.
} 
Table 1. Taxonomy of vertical comparative advantage.

\begin{tabular}{ccc}
\hline VCA & Type & Description \\
\hline Knowledge-Creation Advantage & Structural (Stage 1) & Ability to abstract, innovate, conceive and realize VBVCs \\
Resource Advantage & Structural (Stage 2) & Possess natural resources, renewable and non-renewable \\
Labor Advantage & Arbitrage (Stage 2) & Abundant, cheap labor (skilled and unskilled) \\
Capital Advantage & Arbitrage (Stage 2) & Abundant, cheap capital (long-term and short-term) \\
\hline
\end{tabular}

erate VAVCs or to the presence of natural resources (Stage 2). ${ }^{10}$ Arbitrage vertical comparative advantage refers to short-run comparative advantage- that is comparative advantage that owes to capital and labor factor-cost price differentials which are the result of the relative abundance of these factors in the region/country. The distinguishing feature here is mobility. Structural advantages are immobile, while arbitrage ones are not. More specifically, arbitrage advantages can be eliminated over time as factors move across regions/countries.

As these factor inputs are mobile, it stands to reason that any resulting vertical comparative advantage will, owing to arbitrage activity, be eliminated over time either by an increase in the demand for the factor in question, by an outflow of the factor input to other regions/countries (as owners of the factor look for a higher return), or by a combination of these two. For example, low wages in a given region/country will prompt labor intensive firms to localize in the region/country but will prompt workers to emigrate to high-wage regions/countries. ${ }^{11}$

\subsection{Vertical Comparative Advantage in the Presence of Perfect Labor and Capital Mobility}

Thus far, we have assumed that factors are immobile across regions/countries. Firms localize the various links of their value chains according to relative factor abundance/relative factor prices, giving rise to geographicallydispersed global value chains. In this section, we ask the counterfactual question, what if arbitrage vertical comparative advantage-based factors (e.g. labor and capital) were perfectly mobile? That is, they could cross borders (region/country borders) costlessly and instantaneously, much like financial capital does today? What then would determine vertical comparative advantage?

The answer: structural comparative advantage. Well-endowed vision-producing and resource regions/countries would have a structural vertical comparative advantage. For example, in a world of perfect labor and capital mobility, Silicon Valley would continue to have a structural vertical comparative advantage in the conception of new IT products. As capital and labor would be identical across regions/countries, it would follow that it may or may not actually manufacture these products (e.g. the iPhone which was conceived of in Silicon Valley, but produced globally). Similarly, Milan would continue to have a structural vertical comparative advantage in designing new lines of clothing (fashion). Again, it may or may not manufacture these products. Resource-rich countries like Canada would, in such a world, continue to have a resource-based structural vertical comparative advantage, as would Africa and Australia. Arbitrage vertical comparative advantage would, on the other hand, not exist for obvious reasons. As factors could move seamlessly across borders instantaneously, responding to factor-price differentials, the law of one price would hold. In short, arbitrage-based vertical comparative advantages would, in the long run all but disappear, leaving structural vertical comparative advantage as the ultimate arbitrager in so far as interregional and international trade goes. Regions/countries would either have a visionsaugmented vertical comparative advantage, a resource-based vertical comparative advantage, some combination of the two, or no vertical comparative advantage whatsoever. It is important to point out that it is not inconceivable for a region/country to have both a VAVC and resource-based vertical comparative advantage. For example, a region/country could be adept at the conception of Stage 1 VAVCs as well as be well-endowed resource-wise. The corresponding Stage 2 manufacturing activity could, however, be localized elsewhere.

Hence, one could argue that vertical comparative advantage in the long-run is affected primarily by structural

${ }^{10}$ VAVC-based Stage 1 structural vertical comparative advantage is similar but not analogous to classical Ricardian comparative advantage. The latter is technology-based (i.e. knowledge) while the former is process-based (i.e. the process of generating knowledge). One could, however, argue that Great Britain held a structural vertical comparative advantage in steam-based process technologies at the start of the $19^{\text {th }}$ century as evidenced by the stream of innovations that followed James Watts' original steam engine. Examples include the high-pressure steam engine and Charles Parsons' Steam Turbine.

${ }^{11} \mathrm{~A}$ good example of the transitory nature of arbitrage vertical comparative advantage is the current decline in popularity of various foreign direct investment localizations in Asia at the hands of lower-wage localizations such as Vietnam, Burma and Laos. 
factors, not arbitrage ones, a fact borne out amply by history. Great Britain did not develop a vertical comparative advantage in feedstock processing on account of its capital, labor or energy endowment; rather, its vertical comparative advantage owed to its ability to generate new products and processes (i.e. knowledge-based vertical comparative advantage). Once developed, traditional factors (labor especially) found their way to England (from Ireland and Scotland) to oversee the workings of the new power drive technology known as the steam engine. It is also borne out by industrial policy throughout Western industrialized countries which is overwhelmingly based on R \& D and product niches (i.e. Michael Porter's clusters and diamonds). Also, it validates and refines the factor-proportions approach to trade. Specifically, long-run vertical comparative advantage is ultimately based on a region/country's relative endowments of knowledge and resources. Traditional factor inputs, being increasingly mobile, have less bearing on vertical comparative advantage. Good examples of this are the many outsourcing and plant relocalizations of the past two decades. As wages and interest rates adjust, it is quite conceivable that no one region/country hold a vertical comparative advantage in capital-, labor- or energy-intensive industries which would leave the two structural vertical comparative advantages.

\section{The GFPH: The Evidence}

As pointed out, one of the innovative features of the generalized factor proportions hypothesis is the unit of analysis, namely value added at the link/stage/task level as opposed to whole value-chain or good level. Not surprisingly, this has far-reaching implications in so far as empirical work is concerned. Given the presence of global value chains (both historically and presently), it stands to reason that tests using value of shipments data will be flawed and consequently of little scientific value (regardless of the findings). Ideally, value added data would be required for obvious reasons, not the least of which would be to avoid double, triple or quadruple counting. Today, there are few products that are produced entirely in a single region/country. The tendency towards the increasingly geographical fragmentation of value chains was accentuated in the 1980s by the energy crisis and the productivity slowdown. Increasingly, large multinational corporations outsourced links/stages/ tasks and strands of links of their manufacturing operations (links in the value chain) to low-wage countries. As value-added trade data are not available (and unlikely to be available in the near future), we propose an alternative approach to testing or verifying the validity of the generalized factor proportions hypothesis presented in this paper. In a nutshell, it consists of (i) reinterpreting the results of existing tests in light of the predictions of the GFPH, and (ii) offering a series of indirect tests using Belassa indices of vertical comparative advantage and hence international trade.

\subsection{Existing Empirical Results Seen through the GFPH}

We begin by reexamining previous empirical findings from the point of view of the generalized factor-proportions hypothesis. Operationally, this involves reinterpreting existing evidence in terms of link/stage/task localization. We begin with Wassily Leontief's early tests of the HOH using US post-war data [35]. In the 1950s, Leontief, the father of input-output analysis in the US, set out to test the Heckscher-Ohlin based [1] prediction that because the US was a capital rich country, its exports would be capital intensive, while its imports would be labor intensive. Not surprisingly, this view subsumed a number of things, notably that US exports and imports were entirely produced in the US and its trading partners, respectively. History, however, shows this to be an erroneous assumption. By the mid-1950s, the US had exhausted many of its resources (iron ore, forests, oil) and had become a net importer. Its strength lies in its ability to transform imported resources into US VAVC-based commercially-viable goods and services. Cast in terms of value chains, US activity was increasingly becoming concentrated in downstream Stage 2 links (manufacturing).

While a surprise - and indeed a paradox - to most, the fact that US imports were found to be more capitalintensive than its exports is consistent with the GFPH. Raw material extraction and processing are highly capital-intensive activities, while manufacturing is, on average, more labor intensive. The US's vertical comparative advantage at the time was in (i) the Stage 1-based conception of VAVC value chains, and (ii) mid-stream manufacturing. While absent from Leontief's analysis, we speculate that the R \& D intensity of US exports at the time was significantly greater than the R \& D intensity of its imports.

It is worth noting that this result is not inconsistent with the commonly-held view (at the time) that the US was wealthier than its trading partners if allowance is made for direct and indirect foreign investment. As it turns out, many of the overseas companies exploiting and exporting resources to the US were vertically-integrated US multinational branch plants. So in actual fact, the US was de facto importing its own capital, not that of foreign- 
ers. A good example of this is US iron-ore imports from Canada in the 1950s, more specifically from the USbased Iron Ore of Canada Corporation in Northern Quebec.

Our second set of previous findings is taken from Harry Bowen, Edward Leamer and Leo Sveikauskas' 1987 American Economic Review paper entitled "Multicountry, Multifactor Tests of the Factor Abundance Theory", and consists of their estimates of the ratio of adjusted net trade in factors to national endowment for twentyseven countries and twelve factors presented in Table 2. We see that countries (e.g. Argentina, Australia, Canada) that export primary-sector commodities (SITC 1 - 4) are also net exporters, factor-input wise, of Capital, Agriculture, Arable, Forest and Pasture, while those (e.g. France, Germany, Switzerland, UK) that export manufactures (SITC 5 - 9) are net exporters of Labor, Prof/Tech, Manager, Clerical, Sales and Service. The

Table 2. Bowen, Leamer and Sveikauskas’ empirical results.

\begin{tabular}{|c|c|c|c|c|c|c|c|c|c|c|c|c|}
\hline Country & Capital & Labor & Prof/Tech & Manager & Clerical & Sales & Service & Agriculture & Production & Arable & Forest & Pasture \\
\hline Argentina & 1.32 & -0.30 & -1.64 & -2.60 & -1.07 & -0.62 & -0.83 & 4.30 & -1.46 & 21.24 & -6.94 & 2.40 \\
\hline Australia & -3.77 & -0.41 & -2.95 & -1.79 & -1.68 & 0.21 & -0.11 & 18.10 & -3.65 & 17.15 & -13.68 & 0.80 \\
\hline Austria & -2.03 & 3.01 & 2.74 & 5.64 & 2.91 & 3.81 & 3.20 & 3.12 & 2.59 & -80.74 & 13.52 & 24.35 \\
\hline Bene-Lux & -2.36 & 1.81 & 0.88 & 1.82 & 1.90 & 1.36 & 2.39 & -4.26 & 2.76 & -364.25 & -922.53 & 53.27 \\
\hline Brazil & -5.54 & -0.27 & -0.85 & -0.49 & -0.82 & -0.32 & -0.23 & -0.04 & -0.61 & 2.10 & -0.04 & -0.02 \\
\hline Canada & 1.82 & -3.49 & -3.40 & -2.23 & -4.00 & -2.73 & -1.88 & 4.00 & -6.84 & 12.13 & 6.16 & 2.84 \\
\hline Denmark & -4.89 & 5.82 & 2.37 & 8.70 & 4.25 & 5.08 & 4.51 & 24.56 & 1.21 & 33.57 & 803.73 & 1763.42 \\
\hline Finland & 4.69 & 2.14 & 0.49 & 4.22 & 1.78 & 1.94 & 1.89 & 1.26 & 3.21 & -24.44 & 30.48 & 434.70 \\
\hline France & -4.07 & 0.82 & 0.70 & 1.17 & 1.02 & 0.90 & 1.06 & 0.16 & 1.04 & -21.33 & -198.68 & 1.79 \\
\hline Germany & -1.05 & -0.43 & 1.01 & 1.34 & 0.51 & -1.08 & -1.05 & -11.86 & 2.07 & -323.61 & -377.64 & -124.77 \\
\hline Greece & -5.50 & 2.93 & 4.48 & 14.95 & 5.37 & 4.49 & 4.68 & 2.20 & 2.02 & 46.92 & -61.16 & 1.08 \\
\hline Hong Kong & -46.06 & 4.52 & 5.24 & 3.68 & 8.10 & 3.48 & 3.03 & -14.19 & 6.46 & $-21,568$ & $-30,532$ & $-91,627,216$ \\
\hline Ireland & -1.93 & 6.73 & 4.49 & 13.84 & 7.19 & 6.10 & 8.07 & 10.59 & 2.67 & 17.31 & -129.98 & 72.68 \\
\hline Italy & -7.03 & 0.74 & 1.25 & 4.67 & 1.42 & 0.39 & 1.27 & -1.73 & 1.87 & -39.91 & -431.67 & -131.90 \\
\hline Japan & -5.47 & 0.10 & 0.44 & 0.48 & 0.33 & -0.05 & -0.03 & -1.54 & 1.18 & -341.42 & -268.58 & -1998.58 \\
\hline Korea & -30.51 & 0.61 & 1.53 & 2.85 & 1.81 & 0.76 & 1.73 & 0.27 & 0.85 & -42.34 & -29.42 & 1206.60 \\
\hline Mexico & -0.78 & 0.57 & 0.19 & 0.47 & 0.51 & 0.80 & 0.70 & 0.87 & -0.21 & 12.40 & 5.69 & 0.97 \\
\hline Netherlands & -4.56 & 4.61 & 3.49 & 6.36 & 3.65 & 4.72 & 5.53 & 22.78 & 1.41 & 82.74 & -719.88 & 330.86 \\
\hline Norway & -5.54 & 5.57 & 3.75 & 6.15 & 7.98 & 0.22 & 10.58 & 14.59 & -0.06 & -125.48 & 105.96 & 660.35 \\
\hline Philippines & -13.94 & -0.10 & -0.59 & -0.36 & -0.81 & 0.03 & 0.06 & 0.14 & -0.81 & 10.47 & -8.43 & -17.03 \\
\hline Portugal & -10.31 & 1.92 & 3.92 & 10.85 & 3.75 & 2.83 & 2.72 & 0.63 & 2.49 & -28.46 & 24.79 & 12.03 \\
\hline Spain & -6.19 & 3.04 & 4.56 & 13.88 & 4.36 & 4.13 & 3.89 & 2.45 & 2.23 & -2.74 & -12.00 & 4.92 \\
\hline Sweden & 0.79 & 1.36 & 0.59 & 2.26 & 1.05 & 1.09 & 1.44 & -0.66 & 2.18 & -67.23 & 30.93 & 48.00 \\
\hline Switzerland & -5.72 & 3.42 & 4.46 & 11.57 & 3.52 & 5.42 & 4.13 & -0.79 & 3.04 & -862.95 & -352.36 & -12.18 \\
\hline UK & -12.86 & 0.63 & 1.77 & 2.04 & 1.37 & 1.30 & 1.32 & -18.57 & 1.11 & -313.42 & -2573.99 & -91.89 \\
\hline $\begin{array}{l}\text { United } \\
\text { States }\end{array}$ & 0.08 & -0.25 & 0.23 & -0.11 & -0.19 & -1.10 & -0.68 & 1.54 & -0.34 & 19.45 & -23.82 & -1.63 \\
\hline Yugoslavia & -3.15 & 0.68 & 0.39 & 1.59 & 1.12 & 2.05 & 1.15 & 0.46 & 0.76 & -0.08 & 2.81 & 14.24 \\
\hline
\end{tabular}

Source: [36]. 
Prof/Tech and Manager inputs can be viewed as proxies for the "ability to generate VAVCs Stage 1 structural vertical comparative advantage”. Further, BeneLux, Germany, Hong Kong, Japan, Switzerland and the UK are all net importers of Stage 2 resources. Argentina, Australia and Denmark are resource net exporters and hence can be regarded as having a Stage 2 resource-based vertical comparative advantage.

The US case is prima facie an enigma as it exports capital and imports resources (capital intensive). Also, it imports labor as well as human capital (Labor, Prof/Tech, Manager, Clerical, Sales and Service), unlike other G-6 countries. Specifically, Japan, Germany, France, Italy and Great Britain are all net exporters of Labor and net importers of Capital. This, we argue reflects the nature of Stage 2 value chains in both countries, namely as being primarily downstream (i.e. in labor-intensive Stage 2 links). All are net importers of raw materials (capitalintensive Stage 2 links). However, given both the size and breadth of the US economy (having multiple vertical comparative advantages), more of its exports are capital intensive.

When broken down by value chain and link/stage/task, Bowen, Leamer and Sveikauskas' results are less troublesome. Countries can hold multiple vertical comparative advantages. Seen in this light, seemingly paradoxical results disappear. For example, the Leontief Paradox, the bane of Heckscher-Ohlin trade theory, can be seen as having resulted from (i) confusion over the very nature of value chains in the US and (ii) the corresponding definition of comparative advantage. From the early $20^{\text {th }}$ century, US-based VAVCs relied increasingly on imported raw materials (mineral ores and energy). As US multinationals (Stage 1 VAVCs) localized Stage 2 natural resource links abroad, intra-firm imports became increasingly more capital intensive, while exports became increasingly more labor intensive (owing to Stage 2 US VAVCs' vertical comparative advantage). When combined with an empirically-flawed definition of comparative advantage, namely horizontal comparative advantage, one gets the Leontief Paradox. As we have shown, large federal entities, consisting of many regions, have multiple vertical comparative advantages (Stage 1 and Stage 2). To want to somehow reduce this to a simple $2 \times 2$ or nxm assignment problem is, in our view, a questionable practice. The problem, we argue, can be traced back to early attempts by writers such as David Ricardo and others to compare countries using aggregate measures of horizontal comparative advantage. Clearly, in the presence of foreign direct investment and multinational firms, the US does not have a horizontal comparative advantage in capital-intensive goods, no more so than it has a horizontal comparative advantage in R \& D-intensive goods.

The third set of existing results consists of the findings of Neil Foster, Robert Stehrer and Gaaitzen de Vriees on trade in value added and factors [36]. Specifically, the authors decomposed exports and imports of 35 industries into intermediate goods and final goods, providing export value added as well as capital and labor data, the latter disaggregated by types. Table 3 presents net trade in capital (NEK) and labor (NEL) by use categories intermediates (Int.) and final goods (Fin.). G-6 countries are, in general, net importers of capital, both for intermediates and final goods, as well as net exporters of labor. According to the GFPH, this owes to high capital intensity of imported raw materials, and the high labor intensity of manufacturing activity. For example, France is a net importer of capital and a net exporter of labor, both for intermediates and final goods. That it be a net importer of capital for final goods owes to the capital intensity of fossil fuel imports (petroleum and natural gas). The latter holds true for virtually all G-6 countries. Natural resource-rich countries (Canada, Australia, and Russia) are net exporters of capital and net importers of labor in so far as intermediates are concerned. It is important to point out that most of the capital in these countries is foreign-owned, typically by large vertically and horizontally-integrated G-6-based multinational firms. Their vertical comparative advantage, it therefore follows, lies in the presence of resources (structural vertical comparative advantage).

\subsection{The GFPH and Heterogeneity}

Like most scholars, trade theorists long for regularity and singularity in so far as their results are concerned. In the 1960s and 1970s, they longed to find rich countries (i.e. G-6) exporting capital and importing labor from poorer countries. Instead, they found mixed results, some that were consistent with the theory, while others were abject violations in short, heterogeneity.

While heterogeneity is anathema to $\mathrm{HOH}$, it is consistent with to the point of being predicted by the GFPH. Mobile labor and capital combined against a backdrop of multinational firms (global value chains) are sufficient to generate diverging and divergent results. For example, some multinationals might choose to exploit natural resources at the source (region/country), while others send them for processing elsewhere.

Where the GFPH generates more regularity is with regard to structural vertical comparative advantage. Spe- 
Table 3. Net trade in capital and labor by use categories 2005, US \$ billion.

\begin{tabular}{|c|c|c|c|c|}
\hline Country & NEK-Int. & NEK-Fin. & NEL-Int. & NEL-Fin. \\
\hline Austria & 2.6 & -5.1 & 10.2 & -5.8 \\
\hline Belgium & 0.6 & -3.3 & 20.2 & -3 \\
\hline Denmark & -0.9 & 0.3 & 3.8 & 4.9 \\
\hline Finland & 1.6 & -1.6 & 8 & -1.1 \\
\hline France & -43 & -26.8 & 24.9 & 8.6 \\
\hline Germany & 59.8 & -80.8 & 214.6 & 17.5 \\
\hline Greece & -4.2 & -11.2 & -4.6 & -22.5 \\
\hline Ireland & 23 & 2.1 & -0.6 & -1.1 \\
\hline Italy & -34.5 & -12.9 & 10.6 & 13.1 \\
\hline Luxembourg & 0.4 & 2.4 & 3 & 0.1 \\
\hline Netherlands & 5.6 & -4 & 34.7 & 9 \\
\hline Portugal & -6.2 & -6 & -3.3 & -7 \\
\hline Spain & -35.9 & -10.7 & -34.2 & -14.5 \\
\hline Sweden & 0.6 & 0.9 & 16.1 & 6 \\
\hline United Kingdom & -43 & -48.7 & 26 & -4.5 \\
\hline Bulgaria & -1.5 & -0.8 & -0.3 & -1.1 \\
\hline Cyprus & 1.1 & -1.7 & 1.8 & -2.3 \\
\hline Czech Republic & -2.5 & 2.1 & -1.3 & 3 \\
\hline Estonia & 0.1 & -0.9 & 1 & -0.6 \\
\hline Hungary & -4.1 & 1.6 & -2.3 & 1.1 \\
\hline Latvia & -0.2 & -1.3 & 0.8 & -1.7 \\
\hline Lithuania & -1.1 & -1.1 & 1 & -0.9 \\
\hline Malta & 0.3 & -0.4 & 0.7 & -0.7 \\
\hline Poland & -2.6 & 4.8 & -6.9 & 0.9 \\
\hline Romania & -4.7 & -2.4 & -1 & -2.4 \\
\hline Slovak Republic & -0.8 & -0.1 & -2.2 & -0.6 \\
\hline Slovenia & -1.1 & 0.3 & 0.5 & 1.2 \\
\hline Turkey & -23.1 & -4.9 & -8.4 & 3.2 \\
\hline Canada & 73.9 & -41.3 & 69.6 & -62.9 \\
\hline United States & -251.6 & -202.5 & -126.2 & -141.1 \\
\hline Mexico & 29.1 & 11.4 & -35 & -12.2 \\
\hline Japan & -33.1 & 30.7 & 42 & 46.5 \\
\hline South Korea & -12.3 & 10.3 & 13.9 & 25.6 \\
\hline Taiwan & 2.6 & -3.1 & 24.1 & -1 \\
\hline Australia & 59 & -57.9 & 30.4 & -35.2 \\
\hline Brazil 1 & 5.7 & 6 & 9.5 & 4.6 \\
\hline China & -32.7 & 132.6 & -21.8 & 139 \\
\hline Indonesia & 30.2 & -5.4 & -0.5 & -6.2 \\
\hline India & 5.3 & 25.4 & -17.4 & -1 \\
\hline Russia 1 & 22.6 & -11.1 & 44.7 & -40.5 \\
\hline Rest of World & 105.2 & 315.2 & -346 & 120.8 \\
\hline
\end{tabular}

Source: [37]. 
cifically, it maintains that the ability to generate VAVCs and natural resource endowments are the two trade anchors in so far as net factor exports and imports are concerned. This owes to their immobility. Specifically, while products and processes can be exported or imported, the ability to conceive them cannot. The GFPH predicts that while the predictions regarding traditional factor inputs will yield mixed results, these will not. Regions and countries that are well endowed with visionaries will continue to be net exporters of headquartering activity, while countries that are well endowed with resources will continue to be net exporters of resources.

\subsection{Evidence of GFPH-Based International Trade}

In this section, evidence of the GFPH at the regional level (within the US) and at the country level is provided. To begin with, data on R \& D spending and headquartering activity by US state will be used to draw inferences on the ability to generate Stage 1 VAVCs. The basic idea here is that R \& D and visions are, geographically speaking, collinear. Regions within the US that are R \& D rich are also more likely to generate VAVCs. This will be followed by an attempt to draw inferences about country-level vertical comparative advantage from a series of Balassa factor intensity indices. It should be kept in mind that these findings are, at best, suggestive given the limitations of the data (value of shipments).

We begin with US interstate (inter-regional) trade, the underlying idea being that value chains in the US are geographically dispersed across the fifty states according to vertical comparative advantage. That is, resourcerich states will process and export resources (Stage 2), while knowledge-rich states will, on average, produce and export Stage 1 knowledge/visions (VAVCs). Given the presence of perfect (or near perfect) labor and capital mobility within the US it stands to reason that no one state will have an arbitrage vertical comparative advantage, putting all of the focus on structural vertical comparative advantages. ${ }^{12}$ Two proxies are used for the presence of a knowledge-based, visions-generating structural vertical comparative advantage, namely research and development expenditure by state and, secondly, the number of Fortune 500 companies by state. Both, we argue, are proxies for the presence of a VAVC-generating culture, one that ultimately gives rise to new firms, products/services and material processes. Research and development expenditure by state is used as a proxy for the state's ability to generate VAVCs and hence have the corresponding structural vertical comparative advantage. It is important to note that this does not imply that the state in question will ultimately produce the good/ service in question, but rather that the state is the cradle of the VAVC.

Table 4 presents total R \& D spending by state for 1997, gross state product (GSP), the ratio of the former to the latter, the state's share of overall $\mathrm{R} \& \mathrm{D}$ (Column 7), the corresponding rank (Column 6), and lastly the number of Fortune 500 firms (Column 8). Heading the list is capital and labor mobility, one in which structural factors would determine vertical comparative advantage. Perfect labor and capital mobility within the US makes for a situation in which knowledge and resources become the relevant comparative advantage criteria.

California with R \& D spending of \$41 billion, a GSP of \$1 trillion and 52 Fortune 500 firms. Next comes Michigan and New York with \$13 and \$12 billion in R \& D, and 22 and 57 Fortune 500 firms, respectively. Whether measured in terms of Fortune 500 headquarters or R \& D spending, there can be little doubt: the Golden State and the Empire State have an important vertical comparative advantage in the generation of knowledge. One could argue that the first fifteen states on the list (from California to Minnesota) have a similar advantage, albeit of a lesser degree. New Jersey and Massachusetts both have a knowledge-based structural vertical comparative advantage. The bottom fifteen, it stands to reason, do not have such an advantage. States such as South Dakota, Wyoming, Alaska and Maine have a comparative vertical disadvantage when it comes to knowledge generation. It also stands to reason that their structural vertical comparative advantage, if it exists at all, will lie with their natural resources. It is well known that most of these states produce and export raw materials.

It is important to keep in mind that these results are suggestive of a pattern, of a trend, and not definitive. That California has a vertical comparative advantage in the conception of products and processes does not preclude the presence of an important mining sector in the state, nor does it preclude manufacturing. However, given that capital and labor are perfectly mobile within the US, one cannot infer the presence of a labor or capital-based arbitrage vertical comparative advantage. Similarly, they do not preclude the emergence of VAVCs in Colorado, Montana or Wyoming. A good example is Minnesota, a longtime resource-rich state that is also the home of 3M, a Fortune 500 company.

\footnotetext{
${ }^{12}$ Seen in this light, the internal US market is a metaphor for a world economy characterized by unfettered free trade.
} 
Table 4. Total R \& D and GSP, by State, 1997.

\begin{tabular}{|c|c|c|c|c|c|c|c|}
\hline Rank & State & $\mathbf{R} \& \mathbf{D}$ & GSP & $R$ \& D/GSP & Rank & R \& D/Total & Fortune 500 \\
\hline 1 & California & 41,670 & $1,033,016$ & 4.03 & 9 & 19.72 & 52 \\
\hline 2 & Michigan & 13,991 & 272,607 & 5.13 & 3 & 0.62 & 22 \\
\hline 3 & New York & 12,307 & 651,652 & 1.89 & 25 & 5.83 & 57 \\
\hline 4 & New Jersey & 12,067 & 294,055 & 4.1 & 8 & 5.71 & 24 \\
\hline 5 & Massachusetts & 11,097 & 221,009 & 5.02 & 4 & 5.25 & 10 \\
\hline 6 & Texas & 9487 & 601,643 & 1.58 & 28 & 4.49 & 56 \\
\hline 7 & Pennsylvania & 8209 & 339,940 & 2.41 & 15 & 3.89 & 25 \\
\hline 8 & Illinois & 8034 & 393,532 & 2.04 & 21 & 3.8 & 33 \\
\hline 9 & Washington & 7543 & 172,253 & 4.38 & 6 & 3.57 & 10 \\
\hline 10 & Maryland & 7395 & 153,797 & 4.81 & 5 & 3.5 & 6 \\
\hline 11 & Ohio & 7145 & 320,506 & 2.23 & 17 & 3.38 & 28 \\
\hline 12 & Florida & 4784 & 380,607 & 1.26 & 31 & 2.26 & 12 \\
\hline 13 & North Carolina & 4667 & 218,888 & 2.13 & 18 & 2.21 & 14 \\
\hline 14 & Virginia & 4136 & 211,331 & 1.96 & 23 & 1.96 & 17 \\
\hline 15 & Minnesota & 3605 & 149,394 & 2.41 & 16 & 1.71 & 20 \\
\hline 16 & Connecticut & 3454 & 134,565 & 2.57 & 12 & 1.63 & 11 \\
\hline 17 & Colorado & 3205 & 126,084 & 2.54 & 13 & 1.52 & 12 \\
\hline 18 & Indiana & 3149 & 161,701 & 1.95 & 24 & 1.49 & 5 \\
\hline 19 & New Mexico & 3028 & 45,242 & 6.69 & 1 & 1.43 & 0 \\
\hline 20 & DC & 2768 & 52,372 & 5.29 & 2 & 1.31 & 2 \\
\hline 21 & Arizona & 2410 & 121,239 & 1.99 & 22 & 1.14 & 4 \\
\hline 22 & Georgia & 2272 & 229,473 & 0.99 & 38 & 1.08 & 15 \\
\hline 23 & Wisconsin & 2256 & 147,325 & 1.53 & 30 & 1.07 & 9 \\
\hline 24 & Missouri & 1826 & 152,100 & 1.2 & 33 & 0.86 & 10 \\
\hline 25 & Alabama & 1637 & 103,109 & 1.59 & 27 & 0.77 & 1 \\
\hline 26 & Tennessee & 1566 & 146,999 & 1.07 & 36 & 0.74 & 9 \\
\hline 27 & Oregon & 1520 & 98,367 & 1.54 & 29 & 0.72 & 1 \\
\hline 28 & Utah & 1381 & 55,417 & 2.49 & 14 & 0.65 & 1 \\
\hline 29 & Kansas & 1351 & 71,737 & 1.88 & 26 & 0.64 & 1 \\
\hline 30 & Idaho & 1270 & 29,149 & 4.36 & 7 & 0.6 & 2 \\
\hline 31 & Delaware & 1089 & 31,585 & 3.45 & 11 & 0.52 & 1 \\
\hline 32 & Rhode Island & 1040 & 27,806 & 3.74 & 10 & 0.49 & 2 \\
\hline 33 & South Carolina & 1040 & 93,259 & 1.11 & 35 & 0.49 & 1 \\
\hline 34 & Iowa & 980 & 80,479 & 1.22 & 32 & 0.46 & 1 \\
\hline 35 & New Hampshire & 799 & 38,106 & 2.1 & 19 & 0.38 & 0 \\
\hline
\end{tabular}




\begin{tabular}{cccccccc} 
Continued & \multicolumn{1}{c}{} & & & & \\
\hline 36 & Oklahoma & 644 & 76,642 & 0.84 & 40 & 0.3 & 4 \\
37 & Louisiana & 554 & 124,350 & 0.45 & 50 & 0.26 & 3 \\
38 & Kentucky & 526 & 100,076 & 0.53 & 46 & 0.25 & 6 \\
39 & Nevada & 517 & 57,407 & 0.9 & 39 & 0.24 & 2 \\
40 & West Virginia & 427 & 38,228 & 1.12 & 34 & 0.2 & 0 \\
41 & Mississippi & 370 & 58,314 & 0.63 & 43 & 0.17 & 0 \\
42 & Vermont & 314 & 15,214 & 2.06 & 20 & 0.15 & 0 \\
43 & Nebraska & 275 & 48,812 & 0.56 & 44 & 0.13 & 5 \\
44 & Hawaii & 275 & 38,024 & 0.72 & 42 & 0.13 & 0 \\
45 & Arkansas & 272 & 58,479 & 0.46 & 49 & 0.13 & 5 \\
46 & Montana & 199 & 19,160 & 1.04 & 37 & 0.09 & 0 \\
47 & Maine & 149 & 30,156 & 0.49 & 48 & 0.07 & 1 \\
48 & Alaska & 136 & 24,494 & 0.55 & 45 & 0.06 & 0 \\
49 & North Dakota & 116 & 15,786 & 0.73 & 41 & 0.05 & 0 \\
50 & Wyoming & 87 & 17,561 & 0.5 & 47 & 0.04 & 0 \\
51 & South Dakota & 71 & 20,186 & 0.35 & 51 & 0.03 & 0
\end{tabular}

Source: [15].

\subsection{Further International Evidence}

As previously mentioned, in an ideal world, trade statistics would be reported on a value-added basis, making the task at hand (providing evidence) all the more easier. As the above data on the US economy make abundantly clear, regions and countries are highly heterogeneous in their makeup, making it difficult, if not impossible, to categorize them (e.g. capital abundant, labor abundant, etcetera). Large federal political entities like the US, Canada, Australia, France, Great Britain and Germany consist of multiple heterogeneous regions, each with any number of vertical comparative advantages. What follows is an attempt at categorizing countries according to their dominant vertical comparative advantage, despite the limitations to this approach raised in this paper (see Introduction). We begin by examining the relationship between traditional factor intensities (HeckscherOhlin) and knowledge-based structural vertical comparative advantage.

Table 5 presents three factor intensities for each of the 142-digit SIC industries listed, specifically the ratio of research and development expenditure to overall sales, electric power consumption to labor and the ratio of capital to labor. The results show that primary and intermediate products (upstream-value-chain links) are, on the whole, more electric power and capital intensive and less research and development intensive than finished products. For example, the capital-labor and electric power-labor ratios in SIC 29, Petroleum and Coal Products, SIC 26, Paper and Allied Products, and SIC 33, Primary Metal Industries are $\$ 169808.60$ and 377,521 kWh per worker, \$58443.99 and 154,278 kWh per worker, and \$58,407.28 and 205,442 kWh per worker, respectively. Conversely, in SIC 36, Electric and Electronic Equipment, SIC 37 Transportation Equipment, and SIC 35, Machinery, except Electrical, these ratios are \$14473.98 and 20,870 kWh per worker, \$20775.98 and 24,717 kWh per worker, and $\$ 18500.16$ and 19,248 kWh per worker, respectively.

These three factor intensities were used to construct Balassa indives of the relative factor content of trade. Specifically, weighted (by trade flows) averages of the R \& D content, the electric power-labor ratio, and the capital-labor ratio of exports and imports were calculated for 110 countries. The weights in this case were derived using United Nations export/import data by industry. Table 6 presents the results for five countries, namely the US, Japan, Canada, Australia and Norway. Referring to Column 2, we see that average R \& D intensity for US exports and imports are 2.79 percent and 2.04 respectively, making the US a net exporter of R \& D. The corresponding capital-labor and energy-labor indices show the US to be a net importer of capital and 
Table 5. Two-digit SIC industry factor intensities.

\begin{tabular}{ccccc}
\hline SIC & Industry & R \& D/GDP & k/n (\$) & e/l (kWh) \\
\hline 20 & Food and Kindred Products & 0.4 & 40,801 & 39,756 \\
22,23 & Textiles and Apparel & 0.4 & 9453 & 21,149 \\
24 & Lumber, Wood Products & 0.8 & 12,657 & 28,339 \\
26 & Paper and Allied Products & 0.9 & 58,443 & 154,278 \\
28 & Chemicals and Allied Products & 3.6 & 107,263 & 266,175 \\
29 & Petroleum and Coal Products & 0.7 & 169,808 & 377,521 \\
30 & Rubber and Plastic Products & 2.4 & 24,403 & 39,788 \\
32 & Stone, Clay and Glass Products & 1.2 & 35,431 & 64,297 \\
33 & Primary Metal Industries & 0.8 & 58,407 & 205,442 \\
34 & Fabricated Metal Products & 1.2 & 16,969 & 20,686 \\
35 & Machinery & 5 & 18,500 & 19,248 \\
36,48 & Electronic Equipment & 6.3 & 14,473 & 20,870 \\
37 & Transportation Equipment & 3.1 & 20,775 & 24,717 \\
\hline
\end{tabular}

Source: [38].

Table 6. Factor content of trade: US, Japan, Canada, Australia and Norway.

\begin{tabular}{ccccc}
\hline Index & US & Japan & Canada & Australia \\
\hline $\mathrm{R} \& \mathrm{D}_{\text {exports }}$ & 2.79 & 3.51 & 1.95 & 0.93 \\
$\mathrm{R} \& \mathrm{D}_{\text {imports }}$ & 2.04 & 1.14 & 2.93 & 2.94 \\
$\mathrm{k} / \mathrm{n}_{\text {exports }}$ & 40,278 & 25,086 & 60,047 & 60,378 \\
$\mathrm{k} / \mathrm{n}_{\text {imports }}$ & 81,065 & 116,396 & 41,210 & 53,436 \\
$\mathrm{e} / \mathrm{n}_{\text {exports }}(\mathrm{kWh})$ & 75,335 & 43,083 & 126,795 & 113,909 \\
$\mathrm{e} / \mathrm{n}_{\text {imports }}(\mathrm{kWh})$ & 173,257 & 254,383 & 80,355 & 236,016 \\
\hline
\end{tabular}

Source: [15].

energy. That is, US imports are more capital and energy intensive than its exports, confirming Leontief's paradoxical findings. It is important to remember that upstream industries (raw materials and intermediate goods) are more capital and energy intensive than downstream industries. This allows us to infer that the US's dominant vertical comparative advantage lies in the Stage 1 conception of VAVCs link as well as in downstream laborintensive industries (manufacturing). Again, it is important to keep in mind the summary nature of these results. While the US imports raw materials, it also produces raw materials; likewise, while it exports finished goods, it also imports finished goods.

Consider next the four other countries, Japan, Canada, Australia and Norway. The Japanese results are similar to those of the US: a net exporter of R \& D and labor and a net importer of capital and energy (resource). Interestingly, it exports more R \& D and imports more capital and energy than the US, a fact that can be attributed to the more homogeneous structure of its economy - that is, not having raw materials, its activities are concentrated in manufacturing. The US and Japanese cases contrast with the latter three cases where each country is a net importer of R \& D and a net exporter of capital and energy. In the case of Norway, a dollar's worth of exports has less than one cent of R \& D content, while a dollar's worth of imports has three cents of R \& D content. Clearly, Norway's dominant vertical comparative advantage is resource based, a finding corroborated by the 
generally-accepted view of Norway as a resource-abundant country, especially with its share of North Sea oil. All three are resource-abundant countries which explain the relatively low R \& D and high capital and energy content of their net exports. Cast in terms of Equation (7), all three attract direct foreign investment in the upstream strand (s) of Stage 2 global value chains. For example, Canada's abundant forests, minerals, and fossil fuels provide it with a resource-based structural vertical comparative advantage. Historically, these resources have been exploited by foreign multinational firms that localized and continue to localize their up-stream operations/links in the provinces of Quebec, Ontario, British Columbia and Alberta. It is important to note that this does not rule out the presence of knowledge-based vertical comparative advantages in these countries/regions as evidenced by non-zero levels of R \& D expenditure. In other words, Canadian, Australian and Norwegian VAVCs do nonetheless exist as evidenced by the existence of Canadian, Australian and Norwegian multinational firms.

These results are corroborated by data on R \& D spending at the country level. The US and Japan spent considerably more on R \& D than do the others. For example, the US and Japan spend roughly 2.70 and 2.98 percent of their GDP on R \& D, respectively while Canada, Australia and Norway spend 1.93, 1.53 and 1.70 percent, respectively. While Canada, Australia and Norway have made greater R \& D a policy objective (as have most OECD countries), their overall foreign trade is, in general, still very much dominated by their resourcebased Stage 2 structural vertical comparative advantage. Again, this is not to say that all regions within these countries have a resource-based structural vertical comparative advantage, but rather that the countries taken as a whole do. Also, as pointed out earlier, it does not preclude the existence of knowledge-based structural comparative advantages. For example, despite its important resource-based vertical comparative advantage, Canada has knowledge-based vertical comparative advantages in a number of sectors, including transportation, food processing and entertainment. The same holds in the case of Norway which despite its resource-based vertical comparative advantage has a knowledge-based Stage 1 vertical comparative advantage in the machine tool sector.

\section{The GFPH and Trade Policy}

The Ohlin-Samuelson formalization of the HOH suffers from a number of shortcomings not the least of which is a dearth of policy recommendations. While it offers a convenient framework to study price distortions (tariffs, subsidies) and other market-based distortions (quotas), it offers little in the way of pro-active policy measures - that is, measures designed to alter fundamentals. In its $2 \times 2 \times 2$ version, a country wanting to export more capital-intensive goods (typically referred to as manufactures) has to increase savings with the hope of increasing the rate of capital formation. As technology is a free good, investment in R \& D is irrelevant.

In short, it leaves much to be desired, especially in the current era of R \& D, innovation, Michael Porter's diamond analysis, etcetera. Enter the Generalized Factor Proportions Hypothesis. It is our view that the GFPH presented here addresses the shortcomings of the traditional approach, especially with regard to technology, resources, value chains, and knowledge creation in general. Specifically, it is able to rationalize Michael Porter's diamond approach to the competitive advantage of nations in factor-proportions terms. Specifically, by fostering knowledge creation, a country can increase its advantage in the conception of products and processes (and the corresponding value chains).

In this section, we examine the policy implications of the GFPH. Unlike the HOH, the GFPH has important policy implications. Moreover, as it turns out, most of these are concordant with the policy measures that have been adopted in Western industrialized nations over the course of the past three decades, a finding that further corroborates the empirical validity of the GFPH. As argued, GFPH-based vertical comparative advantages can be either structural or arbitrage in nature. In the case of the former, vertical comparative advantage is based on knowledge and/or resources, while in the latter, it is based on a nation/region's labor or capital endowment.

As each can be affected by government policy, it stands to reason that vertical comparative advantage as defined here can be viewed as an endogenous variable. We begin by examining the first of two types of vertical comparative advantage, namely structural vertical comparative advantage.

Structural vertical comparative advantage consists of either broadly-defined knowledge-based vertical comparative advantage or broadly-defined natural resource-based vertical comparative advantage. A knowledgebased vertical comparative advantage refers to the ability of a given region/country to generate VAVCs. While research and development expenditure is typically invoked as the relevant policy instrument, it is, by no means, 
the only instrument. As we have argued, knowledge is a cultural phenomenon, one that is intimately tied to cultural values. For example, how a society responds to novelty, to change, to new ideas, to new ways of seeing things, are good predictors of its propensity to create knowledge. Closed societies are less likely to innovate and, as such, are less likely to generate knowledge-based vertical comparative advantages.

As cultural values are difficult to define and measure systematically, proxies are oftentimes used. For example, per-capita expenditure on education can be used as a proxy. Societies that invest heavily in education value knowledge more than those that do not. Another possible proxy would be a measure of religious and/or political freedom, the argument being that societies (regions/countries) that accommodate/tolerate different beliefs, are tolerant of differences are more likely to be open to new ways of looking at things-in short, more open to novelty. $^{13}$

A related proxy is the nature of the relevant R \& D institutions. For example, is R \& D organized hierarchically where decisions regarding research programs are taken by majority rule (or by a director) or is it organized along collegial/competitive lines where individual scientists/scholars enjoy considerably more "intellectual freedom?” In many regards, this is analogous to religious freedom. Highly rigid (hierarchical) research environments are analogous to monotheistic cultures, while more collegial/competitive environments are analogous to more tolerant, polytheistic cultures.

Table 7 presents a non-exhaustive list of vertical comparative advantage policy tools, ranging from education, R \& D, to tax policy. Given the existence of two types of advantages, there are two types of tools, namely those aimed at structural vertical comparative advantage and those aimed at affecting arbitrage vertical comparative advantage. Structural vertical comparative advantages have the advantage of being more permanent. An arbitrage vertical comparative advantage can, given the mobility of capital and labor, be ephemeral-here today, gone tomorrow. Tax holidays will attract capital; however, it is not clear that the resulting advantage will be permanent, unless of course it can generate some form of localization-specific knowledge advantage. Likewise, immigration and/or high birth rates may result in an arbitrage vertical comparative advantage; however, labor market conditions abroad may evolve in such a way so as to eliminate it.

Of the policy tools listed in Table 7, education and R \& D are by far the most utilized. Whereas prior to the 1980s government policy focused on macroeconomic stabilization (Keynesian), since, governments have sought to foster the creation of knowledge with two goals in mind, namely increasing overall growth and generating comparative advantage [39]. As growth is assumed to be increasing in exports, it stands to reason that countries will want to invest massively in knowledge. Which is, to a large extent, precisely what we observe. Governments, ranging from federal to state to municipal have, over the course of the past two decades, adopted policies aimed at generating structural vertical comparative advantages for their city/state/country.

Another important policy implication of our analysis relates to welfare analysis. In the majority of cases, government-sponsored investment in education and R \& D is motivated by a number of considerations, the most important of which is job and wealth creation. For example, the government of Brazil has invested heavily in its aeronautics industry by way of subsidies, loans and tax breaks for Embraer Corporation, its foremost multinational firm. However, given the spatially diffuse nature of value chains (i.e. global value chains), it is by no means clear that the creation of a structural vertical comparative advantage will confer wealth upon the region/ country. As we have shown, Stage 1 and Stage 2 in our model are completely independent. Regions/countries that develop VAVCs are not necessarily those that will produce the corresponding goods and services. According to John D. Pepper, former chairman of the board of Proctor and Gamble:

Table 7. Vertical comparative advantage policy tools.

\begin{tabular}{ccc}
\hline VCA & Type & Tools \\
\hline Knowledge Advantage & Structural & Education, R \& D, Arts, Culture \\
Resource Advantage & Structural & Exploration, Sustainable Development \\
Labor Advantage & Arbitrage & Immigration, Fertility, Human Capital \\
Capital Advantage & Arbitrage & Tax Policy \\
\hline
\end{tabular}

\footnotetext{
${ }^{13}$ [21] empirically demonstrated that R \& D content in international trade is an increasing function of a number of cultural values, including expenditure on education, number of book titles published, and political and religious freedom.
} 
I will start by discussing the importance of global innovation leadership. In our businesses, innovation leadership, not just in the US but globally, is vital to building market leadership and a strong economic position here in the United States. Why? There are two reasons. First, there are major scale advantages that come from being global. We're able to purchase raw and packaging materials from the best and most capable global suppliers. This not only lowers costs but permits suppliers to invest in their own discovery research that can lead to stronger product innovation. Probably even more importantly, global $R \& D$ capability gives us access to leading-edge scientific developments, technologies, and new ideas, wherever they exist. Our competitors scour the world for the best ideas. We must do the same; indeed we must be ahead of them. Otherwise, we will lose our leadership position, not only abroad, but also here in America. This I think we'd all agree is not debatable. [36]

\section{Summary and Conclusions}

Finding the $\mathrm{HOH}$ version of the FPH to be theoretically and empirically incomplete, especially with regard to technology (endogenous technological change) and institutions (the presence of geographically-dispersed value chains, immobile factor inputs), this paper set out to rehabilitate the factor proportions hypothesis of trade, be it regional or international. The gist is simple and straightforward, and turns around a fundamental oversight in Eli Heckscher and Bertil Ohlin's pioneering work, namely the absence of endogenous technology and multinational firms. What is surprising is the fact that the 1910s, 1920s and 1930s were decades of massive technological change, which altered trade patters significantly, if not paradigmingly. Once sufficient allowance is made for endogenous technology (specifically via a country's endowment of VAVCs) and for spatially-dispersed value chains, the predictions of the GFPH are consistent with the data. Also, the Leontief Paradox is rationalized as are the conflicting and conflicted findings of Harry Bowen, Edward Leamer and Leo Sveikauskas, and Neil Foster, Robert Stehrer and Gaaitzen de Vries.

The resulting General Factor Proportions Hypothesis upholds the view that factor endowments are the basis of trade. It is sufficiently general to allow for both mobile and immobile factors. In its most realistic form, knowledge (read: knowledge generation) and natural resources are viewed as being immobile while capital and labor are mobile, thus giving rise to two types of vertical comparative advantage (VCA), namely structural and arbitrage. As such, regions/countries can be ranked according to their factor proportions-based vertical comparative advantages. Moreover, governments can through the judicious use of policy affect their VCAs. As was shown, the large majority of trade policy measures (i.e. policy instruments) used today are in keeping with the predictions and recommendations of the model.

Further, the General Factor Proportions Hypothesis as developed here (i) endogenizes Ricardian trade theory (ii) incorporates the concept of value chain (value bush), and (iii) allows for the presence of multinational firms and value chains. More specifically, Ricardian technology-based comparative advantage is modeled in factorproportions terms. Regions and countries that are well-endowed with innovative entrepreneurs/managers will generate more product and process-based VBACs resulting in a Ricardian vertical comparative advantage. Unlike traditional approaches that are based on simple neoclassical production functions, this paper innovates by incorporating the concept of value chain, a key concept in this the era of globalized production, as well as the multinational firm. Altogether, this makes for a more realistic, not to mention compelling, view of interregional and international trade, one that is consilient with the related fields of business strategy, the multinational firm, and process engineering.

\section{References}

[1] Bowen, H.P., Leamer, E. and Sveikauskas, L. (1987) Multicountry, Multifactor Tests of the Factor Abundance Theory. American Economic Review, 77, 791-809.

[2] Trefler, D. (1995) The Case of the Missing Trade and Other Mysteries. The American Economic Review, 85, 10291046.

[3] Trefler, D. and Zhu, S.C. (2010) The Structure of Factor Content Predictions. Journal of International Economics, 82, 195-207. http://dx.doi.org/10.1016/j.jinteco.2010.07.006

[4] Davis, D. and Weinstein, D. (2001) An Account of Global Factor Trade. American Economic Review, 91, $1423-1453$. http://dx.doi.org/10.1257/aer.91.5.1423

[5] Bresnahan, T.F. and Trajtenberg, M. (1995) General Purpose Technologies: Engines of Growth? Journal of Econome- 
trics, 65, 83-108. http://dx.doi.org/10.1016/0304-4076(94)01598-T

[6] Helpman, E. and Trajtenberg, M. (1996) Diffusion of General Purpose Technologies. NBER Working Papers 5773, National Bureau of Economic Research.

[7] Hymer, S.H. (1976) The International Operations of National Firms: A Study of Foreign Direct Investment (1960). MIT Press, Cambridge, MA.

[8] Dunning, J. (1981) International Production and the Multinational Enterprise. George Allen and Unwin, London.

[9] Yeaple, S.R. (2003) The Role of Skill Endowments in the Structure of US Outward Foreign Direct Investment. The Review of Economics and Statistics, 85, 726-734. http://dx.doi.org/10.1162/003465303322369849

[10] Grossman, G. and Rossi-Hansberg, E. (2008) Trading Tasks: A Simple Theory of Offshoring. American Economic Review, 98, 1978-1997. http://dx.doi.org/10.1257/aer.98.5.1978

[11] Baldwin, R. and Robert-Nicoud, F. (2014) Trade-in-Goods and Trade-in-Tasks: An Integrating Framework. Journal of International Economics, 92, 51-62. http://dx.doi.org/10.1016/j.jinteco.2013.10.002

[12] Beaudreau, B.C. (2011) Vertical Comparative Advantage. The International Trade Journal, 25, 305-348. http://dx.doi.org/10.1080/08853908.2011.581610

[13] World Bank (2007) Moving toward Competitiveness: A Value Chain Approach. World Bank, Washington DC.

[14] OECD-WTO (2013) Trade in Value Added Statistics. http://stats.oecd.org

[15] Beaudreau, B.C. (2004) World Trade: A Network Approach. iUniverse, New York.

[16] Mundell, R.A. (1957) International Trade and Factor Mobility. American Economic Review, 47, 321-355.

[17] Helpman, E. (1984) A Simple Theory of International Trade with Multinational Corporations. Journal of Political Economy, 92, 451-471. http://dx.doi.org/10.1086/261236

[18] Power, S. (1987) The Origins of the Heckscher-Ohlin Concept. History of Political Economy, 19, $289-298$. http://dx.doi.org/10.1215/00182702-19-2-289

[19] Eaton, J. and Kortum, S. (2002) Technology, Geography, and Trade. Econometrica, 70, 1741-1779. http://dx.doi.org/10.1111/1468-0262.00352

[20] Porter, M.E. (1985) The Competitive Advantage of Nations. The Free Press, New York.

[21] Beaudreau, B.C. (1989) Entrepreneurial Ability, International Trade, and Foreign Direct Investment. International Economic Journal, 3, 1-22. http://dx.doi.org/10.1080/10168738900080016

[22] Nelson, R.R. and Winter, S.G. (1982) An Evolutionary Theory of Economic Change. Harvard University Press, Cambridge, MA.

[23] Monczka, R.M. and Trent, R.J. (1991) Global Sourcing: A Development Approach. International Journal of Purchasing and Materials Management, 27, 2-8.

[24] Min, H. and Galle, W.P. (1991) International Purchasing Strategies of Multinational US Firms. International Journal of Purchasing and Materials Management, 27, 9-18.

[25] Scully, J.I. and Fawcett, S.E. (2004) International Procurement Strategies: Challenges and Opportunities for the Small Firm. Production and Inventory Management Journal, 35, 39-46.

[26] Lundstedt, S. and Colglazier Jr., E.W. (1982) Managing Innovation: The Social Dimensions of Creativity, Invention and Technology. Pergamon Press, New York.

[27] Griffiths, M.D. and Kickul, J. (2008) The Socioeconomic Determinants of Entrepreneurship and Innovation. The International Journal of Entrepreneurship and Innovation, 9, 231-240. http://dx.doi.org/10.5367/000000008786208722

[28] Hummels, D., Ishii, J. and Yi, K. (2001) The Nature and Growth of Vertical Specialization in World Trade. Journal of International Economics, 54, 75-96. http://dx.doi.org/10.1016/S0022-1996(00)00093-3

[29] Hummels, D., Rapoport, D. and Yi, K. (1998) Vertical Specialization and the Changing Nature of World Trade. Federal Reserve Bank of New York Economic Policy Review, 4, 79-99.

[30] Reimer, J. (2006) Global Production Sharing and Trade in the Services of Factors. Journal of International Economics, 68, 384-408. http://dx.doi.org/10.1016/j.jinteco.2005.07.007

[31] Johnson, R.C. (2008) Factor Trade Forensics with Intermediate Goods. Princeton University Department of Economics Working Paper.

[32] Johnson, R. and Noguera, G. (2008) Accounting for Intermediate Goods and Trade in Value Added. Unpublished Manuscript, Department of Economics, University of California, Berkeley.

[33] Griffiths, M.D. and Kickul, J. (2008) The Socioeconomic Determinants of Entrepreneurship and Innovation. The International Journal of Entrepreneurship and Innovation, 9, 231-240. http://dx.doi.org/10.5367/000000008786208722

[34] Leontief, W. (1953) Domestic Production and Foreign Trade: The American Capital Position Re-Examined. Proceed- 
ings of the American Philosophical Society, 97, 332-349.

[35] Pepper, J.D. (1999) National Benefits from Global R \& D. Industrial Research Institute Annual Meeting, Williamsburg, Virginia. www.ineer.org/Special/PGSpeech990526.pdf

[36] Foster, N., Stehrer, R. and de Vriees, G. (2011) Patterns of Net Trade in Value Added and Factors. Vienna Institute for International Economic Studies, Vienna.

[37] Ibid, 24.

[38] US Department of Commerce (1981) Annual Survey of Manufactures. Bureau of the Census, Washington DC.

[39] OECD (2007) Science, Technology and Innovation Indicators in a Changing World: Responding to Policy Needs. OECD, Paris. 